\title{
Models of Arts Teacher's Professional Development
}

\author{
Reni Haerani ${ }^{1}$, Juju Masunah ${ }^{1}$, Tati Narawati ${ }^{1}$, Endang Rochyadi ${ }^{1} \&$ Mujiarto $^{2}$ \\ ${ }^{1}$ Art Education Postgraduate Study Program, Universitas Pendidikan Indonesia, Jl. Setiabudi 229 Bandung 40154, \\ West Java, Indonesia \\ ${ }^{2}$ Universitas Muhammadiyah Tasikmalaya, Tasikmalaya, Indonesia \\ Correspondence: Reni Haerani, Art Education Postgraduate Study Program, Universitas Pendidikan Indonesia, Jl. \\ Setiabudi 229 Bandung 40154, West Java, Indonesia.
}

Received: July 9, 2020

doi:10.5430/ijhe.v9n6p77
Accepted: August 26, 2020

Online Published: August 28, 2020

URL: https://doi.org/10.5430/ijhe.v9n6p77

\begin{abstract}
This article aims to describe a model of professional development for art teachers in Indonesia. The model includes the ability to carry out basic tasks and functions as educators, namely pedagogical, professional, and social competences, especially for dance teachers in managing and providing education services to children with special needs. This qualitative research employed a descriptive method with literature reviews, observations, and personal experiences for data collection. The findings show that the teacher professional development model has been carried out by (1) the pre-professional phase, (2) the autonomous professional phase, (3) the collegial professional phase, but never the post-professional or postmodern phase. The activities are conducted as workshops, including discussions with colleagues, principals, and supervisors. This research recommends conducting continuous supervision and development to improve teachers' competences in providing equitable services in concordance with the needs of inclusive schools.
\end{abstract}

Keywords: arts teachers, teacher training model, inclusive education, teacher competence

\section{Introduction}

Teachers are professional educators with the main task of educating, teaching, guiding, directing, training, assessing, and evaluating students at the levels of early childhood, primary schools, and secondary schools. Law No. 14, 2005 concerning Teachers and Lecturers (article 8) explains that teacher competencies include pedagogical competence, personal competence, social competence, and professional competence. Pedagogical competence is a teacher's ability to manage to learn. Personality competence includes attitudes and behaviors and independent as well as sustainable self-development. Social competence is the ability of teachers to interact and communicate verbally, written, or using gestures with superiors, colleagues, students, parents, and the community with the principles of brother/sisterhood and a spirit of togetherness. Professional competence is a teacher's ability to master knowledge in the fields of science, technology, and/or arts. The four competencies should exist and integrate into the teacher's performance.

Therefore, as a whole teacher's competence includes: (a) getting to know students in-depth; (b) having a good command of the field of study, both in the content of the respective discipline and teaching materials of the school curriculum (pedagogical content); (c) implementing teaching and learning, comprising of planning and implementation, evaluation of the process and outcomes, as well as follow-up for improvement and enrichment. Finally, everything (d) should continuously develop personality and professionalism (Ngainun Naim, 2009).

In DetikNews, November $24^{\text {th }}, 2017$, Syarifudin Yunus stated that the quality of education in Indonesia still needs to be improved. An increase in the budget allocated by the government for education does not necessarily increase the quality of education. Pedagogical competences, which are the main competences of teachers, have not been encouraging. At the same time, in some Western European countries, there has been a decline in teachers' pedagogical sensitivity. Teachers have difficulty discussing pedagogical problems with parents because the nature of the topic is emotionally charged and because of a lack of a clear pedagogical vision, so they are afraid of moral problems that may occur in the classroom (Klaassen, 2002: 151).

The data above signal the importance of addressing the topic of the teacher's competence to support the implementation of quality education. Biesta and Miedema (2002) explain that the first and foremost task of teachers and schools is a pedagogical task, because it relates to the whole person, the whole sense of a student's identity. 
However, schools often try to control the learning process so much so that aspects that are not as expected are seen as irrelevant or even disturbing (Biesta and Miedema, 2002: 181). The aspects of learning are generally adopted from Bloom's notion (1956: 7-8), as follows: (1) Cognitive domain relating to intellectual learning outcomes consisting of six aspects, namely knowledge or memory, understanding, application, analysis, and evaluation; (2) Affective domain of attitudes comprising of five aspects, namely acceptance, answer or reaction, judgment, organization, or internalization; and (3) Psych motoric domain regarding learning outcomes of skills and the abilities to act. There are six aspects of the psych motoric domain, namely reflexes, basic movement skills, perceptual abilities, harmony or accuracy, complex skill movements, expressive and interpretative movements.

Failure to attend to the whole aspects will be a problem for inclusive schools, especially in multicultural countries applying the policy of inclusivity. Children with special needs attending regular schools require a different service compared with children in general. This is even more apparent considering the significant changes in the $21^{\text {st }}$ century relating to the development and demands of quality education services. Hence, teachers must have and be able to develop pedagogical competencies to provide solutions to pedagogical problems, without ignoring other competences.

In Kompas.com on October 26, 2015, Dendi Ramdhani reports that The Mayor of Bandung declared that Bandung is a city of inclusive education, where all regular education units (both public and private) must accept children with disabilities to make sure that every child in Bandung City has the same rights to access equitable education services (https://regional.kompas.com, accessed August 20 ${ }^{\text {th }}, 2018$ ). This is also supported by the issuance of Regional Regulation Number 2 of 2018 concerning the Implementation of Education in the Education Unit, especially in Article 8, which states that "City regional governments manage the National Education System at the regional level to ensure the implementation of inclusive and equitable education and encourage life-long learning opportunities for people in the City." How this translates for the art teachers in junior high school level is that the teachers are required to properly understand the objectives of inclusive education programmed by the government. A proper understanding of the implementation of inclusive education is necessary for holistic thinking towards the direction of the teaching and learning process in inclusive classes.

In general, school teachers still consider students with special needs a burden in the teaching and learning process. Dance teachers still think that dance in public schools is only for "normal" students. The teachers still believe that students with special needs have difficulties to mingle with other students. Their special needs impede the attainment of the same competencies as general students. Therefore, students with special needs have to get assistance from special assistant teachers. Also, dance teachers in general still have difficulty in choosing the right method in serving both, general students as well as students with special needs at the same time. They also do not have a specific evaluation method for special needs students in regular classes. This has become a major problem, particularly when regular schools carry out inclusive education, especially in the city of Bandung which has declared itself to be the City of Inclusive Education.

Based on preliminary observations in Bandung city schools since 2018, it has been found that teachers' pedagogical competencies have not met the expectations. Especially in terms of designing learning, teachers were still found to conduct teaching and learning without any clear planning; and worse, they tended to copy other teachers' lesson plans. The teaching and learning were also observed to not optimally foster learners' creativity. The same was true for instructional strategies, methods, media, and material development. Very few teachers were able to make some innovations in teaching and learning. The teachers also did not reflect based on the results of evaluations. Hence, there was no significant improvement in their competences. These phenomena were found during the authors' observation in regular schools in 2018 and 2019. The phenomena urgently call for the attention of all relevant parties to realize equitable education for all learners.

Therefore, the present study aims to examine the model of competence development for teachers who teach arts and culture, especially dance in Bandung City, Indonesia. What kinds of a teacher training model to develop teacher's competences?

\section{Literature Review}

\subsection{Teacher's Professionalism}

Hargreaves (2000: 153) identifies and develops teacher's professional development into four phases: (1) the pre-professional phase, (2) the autonomous professional phase, (3) the collegial professional phase, and (4) the post-professional or postmodern phase. In the pre-professional phase, teaching is seen as fulfilling managerial demands, but it is technically simple. The principles and parameters are treated by common sense which does not need to be questioned. A person learns to be a teacher through an internship program, and as a teacher s/he must be upgraded 
through individual trials and errors. At this phase, teachers are amateurs: they only need to do according to their supervisor's more knowledgeable direction (Murray, 1992, p. 495 in Hargreaves, 2000: 156). According to Hargreaves (2000: 157), the pre-professional phase has continued to be dominant in many East Asian countries, not only because of class size constraints and other factors but also because of the importance of cultural conceptions of teaching in schools and families. Attachment to sacred culture (Confucian) is still prevalent in East Asia (Japan, China, Thailand, Vietnam, Myanmar) in the form of various social activities. The strong attachment can also be observed in the field of education. This is problematic, as the attachment to sacred culture can be one of the factors that hinder teacher professionalism in teaching and learning.

The autonomous professional phase is characterized by the singularity of teaching and unquestioned traditions that form it. Pre-service teacher education at the university and the growth of in-service education by experts add weight to the claim towards expertise that is the basis of the rights of autonomy (Hargreaves, 2000: 161). Nevertheless, the benefits of in-service teacher's education are rarely integrated into classroom practice, when individual participants return to school and to colleagues who are not enthusiastic, do not understand, and also do not share learning with them. Finally, pedagogy is largely stagnant because teachers are reluctant or unable to stand out from their colleagues and make any changes more than their own.

In the collegial professional phase, there is an increase in efforts to build a strong collaborative professional culture to develop shared goals, overcome uncertainty and complexity, respond effectively to rapid changes and reforms, create a climate that respects the risks taken and increases them continuously, develop a stronger sense of teacher efficacy, and create a culture of sustainable professional learning for teachers. The latter replaces staff development patterns, which are individual, episodic, and weak with school priorities (Hargreaves, 2000: 165-166). This phase of professionalism is newer than the two previous phases (Hargreaves, 2000: 166).

The post-professional phase occurs at the turn of the millennium or the era of postmodernism. The fate of teacher professionalism in this era is completely uncertain, but it is existing and will be debated, struggling against, and being pulled in various directions in various places at different times. According to Hargreaves (2000), one possible outcome of these processes is new postmodern professionalism. It is broader, more flexible, and more democratic, including groups outside their teachings and concerns compared with their predecessors. Hargreaves (2000) states that the emergence of teacher's professionalism in the postmodern era is aided by social movements that are aware of those who are committed. However, many interests in it lead the teacher to detailed measurement and control of competence frameworks that are arranged narrowly, based on the corporate sector and administrative systems by performance management (Hargreaves, 2000).

Wardoyo et al. (2017: 90) report teacher professionalism in Indonesia is currently at the collegial phase. Collegial or collaborative work among teachers in professional development has become an effective way to address the challenges of curriculum change. Also, it has become a strong motivation to support the learning process and increase teacher professionalism (Wardoyo et al., 2017: 91). In many parts of the world, teacher professionalization is now sponsored by the extraordinary support of governments, bureaucracies, and big businesses. There seems to be enormous interest, both politically and administratively, to identify, compile, and apply professional practice standards to teaching staff.

\subsection{Pedagogical Competence}

Pedagogical competence is the ability of teachers in managing learners' learning. This is a necessary competence for teachers to be able to educate the nation. Furthermore, regarding National Education Standards in Government Regulation No. 19/2005, article 28 paragraph (3) point (a), pedagogical competence is defined as the ability to manage learners' learning, including understanding students, designing and implementing learning, evaluating learning outcomes, and developing students to actualize the variety of potentials they have. In that context, teacher competence can be interpreted as the entire knowledge, skills, and attitudes manifested in the form of intelligent and responsible actions possessed by a pre-service teacher to assume the position of a professional teacher.

According to Liakopoulou (2011), the complex and ever-changing role of the teacher makes it impossible to get a clear definition of pedagogical competence. The basic factor that determines this is how expert teaching is defined and conditions are balanced by the teacher who guarantees it. To determine the criteria for evaluating pedagogical competence and choosing evaluation procedures to enter the profession, one must answer the following questions: "a) what qualifications must be possessed by a competent teacher? and b) how can this be evaluated?" (Liakopoulou, 2011: 474). The concept of pedagogical competence also tends to refer to minimum professional standards, including managing learning, which includes planning, implementing, and evaluating student learning outcomes. 
Pedagogical competence is then the ability of teachers in managing learners' learning. In this case, students as the subject of learning are active individuals with various characteristics. Therefore, in the learning process, there should be reciprocal interaction, both between the teacher and students as well as between students and students. Differences in children's characteristics can be influenced by children's distinctive development. Hence, the teacher's development needs to be supported by intellectual abilities and cognitive thinking methods. As argued by Daniel and Cooc (2018: 1), differences in student characteristics can be influenced by intrinsic motivation, be it between teachers and students or between students and students, especially regarding students with intellectual and learning disabilities. Some studies show that students with high intrinsic motivation had better academic performance (Lepper et al., 2005; Taboada et al., 2009). It could be that teachers who have a low level of competence in handling the academic needs of students with severe cognitive or behavioral diagnosis consider these students to have lower academic intrinsic motivation.

From some of the opinions and suggestions above, it is indeed very difficult to become a professional teacher, but it does not mean that becoming a professional teacher is impossible. This requires a strong effort and determination, as well as other factors besides the teachers themselves, such as the government, school, community, and students' parents.

\subsection{Inclusive School/Education}

Inclusive education is an education service system that concerns children with special needs to study in the respective nearest schools in regular classes with friends of the same age, where the school accommodates all students in the same class by providing a decent, challenging education program. It should be adapted to the abilities and needs of each student and the support that can be provided by teachers so that children can succeed (Ministry of National Education, 2012). According to UNESCO (2000) in Puri and Abraham (2004: 25), inclusive education is related to removing all barriers to learning, with the participation of all students who are vulnerable to exclusion and marginalization. This is a strategic approach designed to facilitate learning success for all children. It addresses the general purpose of reducing and overcoming all exceptions to human rights for education, at least at the basic level, and increasing access, participation, and success of learning in quality basic education for all.

Inclusive education does not only mean moving children from the existing special education classes to regular classes. As already explained, there will be no appropriate inclusive education if the existing school system is not reformed to make it friendly for people with disabilities. It is urgent to find the best for the child in each given situation. If the main reason for excluding children from the start is because regular schools fail to meet their needs, it makes no sense to bring them back unless there is a change. As expressed at the Salamanca conference: "The full inclusion of all children in regular schools can only occur as a result of school and the overall education system reforms. This is the whole education system, and not just one aspect that must be reformed so that inclusive education is possible" (Puri and Abraham, 2004: 27). This translates into changes in curriculum and teacher's training; development of support services for schools and classroom teachers; and seeing parents as co-workers; and so on. Therefore, it is necessary to allow flexibility in the methods and materials employed to give these children the widest possible access to the regular curriculum. There is an urgent need to seriously incorporate this into educational practice, to help realize greater acceptance of diversity of children who learn together-learn to live together-when they are young and then as adults (Puri and Abraham, 2004: 27).

In the Provision For Children with Special Education Needs in the Asia Region, James Lynch (1994) reported a summary of research documentation and case studies from 15 countries in the Asian region, about the development and implementation of education for children with special needs, both specifically permanent and temporary ones, especially those who need more serious handling from the teacher, institution, and system. It was stated that children with special needs require special treatment because of several factors: physical, mental, social, emotional, or unfavorable disabilities; or because of a combination of multiple disabilities, so that they could develop their potential as optimally as possible (Lynch, 1994: 1).

Piaget (1999: xi) noted that cognitive development is the result of the relationship between brain development and the nervous system and experiences that help individuals to adapt to their environment. Adaptation is associated with the formal education environment in inclusive schools from the aspect of teaching staff; for example, a teacher is required to have cognitive field competencies. This means that a teacher must have intellectual abilities, such as mastery of subject matter, knowledge of how to teach, and knowledge of how to assess students. 


\subsection{Arts and Culture Teaching and Learning}

Arts and culture are one of the subjects in secondary schools taught by teachers of the specific field of study. The Republic of Indonesia Government Regulation Number 19 of 2005 concerning National Education Standards mandates that culture is not only taught in one subject because it covers all aspects of life. In the subject of arts and culture, culture is not discussed individually but is integrated with art. Therefore, the subject of arts and culture is a culture-based arts education.

Power and Klopper (2011: 2) suggest that arts education provides a very valuable opportunity for students:

Arts education provides students with valuable opportunities to experience and build knowledge and skills in self-expression, imagination, creative and collaborative problem solving, communication, creation of shared meanings, and respect for self and others. Engagement in quality arts education has also been said to positively affect overall academic achievement, engagement in learning, and development of empathy towards others.

The subject of arts and culture consists of four fields of arts, namely dance, fine arts, music, and theater. Among the four art fields, schools should at least teach one field of arts according to the capabilities of their human resources and the available facilities. Based on the 2013 curriculum, arts and culture education in junior high schools serves the function of developing attitudes and abilities in creating something, making artwork, and in creativity and appreciation. One of the branches of arts learned in arts and culture education is dance. Dance is one element of culture in people's lives. Dance is one branch of art that uses the body as a medium of expression. It includes movement skills based on bodywork, with and without sound stimulation, and a form of appreciation of dance movements (Susanto, 2013: 263). Jazuli (2008: 20) argues that the goal of arts education in public schools is not to pass on art skills or expertise but to provide memorable experiences to students to help develop their potentials.

To improve the professionalism of teachers of arts and education, especially in the field of dance, the authors will examine the notion of pedagogical competence. This is in line with Suciu and Măță's (2011) view that the concept of pedagogical competence also tends to be used with the meaning of minimum professional standards, which are often determined by law, which must improve someone in fulfilling certain roles of the teaching profession (Suciu and Māţă, 2011: 413).

Especially in arts and culture teaching and learning in inclusive schools, teacher pedagogical competences greatly determine students' achievements, if supported by the readiness of regular schools in accepting students with special needs, technical readiness, and technology (Mirzagitova and Akhmetov, 2015: 115). Through adequate preparation, the role of professional teachers can deliver students to achieve multiple intelligences through the teaching and learning of arts and culture.

\section{Method}

The present study adopted a qualitative descriptive method. Alwasillah (2011) describes the descriptive method, it intends to outline ways of developing teachers' competences in art and culture at the junior high school level, especially in the city of Bandung, West Java. The data were obtained through literature reviews, observations, and documentary analysis. The sources of data include the teacher's development activities regularly, conducted by the Subject Teachers' Consultative Council or Musyawarah Guru Mata Pelajaran (acronym: MGMP) in the city of Bandung and results of observations that were recorded and compared to other observation results. The data were then analyzed through triangulation, in which the results of observations and literature review were reduced, categorized, synthesized, interpreted, and finally drawn for some conclusions.

\section{Results and Discussion}

In Indonesia, there are many activities to help develop teacher professionalism, such as the portfolio assessment program, Pendidikan Latihan Profesi Guru (acronym: PLPG) or In-Service Teacher Training Program, Program Profesi Guru (acronym: PPG) or Teacher Professional Education, Sustainable Professional Development or Pengembangan Keprofesian Berkelanjutan (acronym: PKB), the Subject Teachers' Consultative Council or Musyarah Guru Mata Pelajaran (Acronym: MGMP), and other education and training programs. A portfolio assessment is carried out not in the form of training but is based on the teacher's track record as displayed in the submitted documents. The teacher's professional education program (PPG) has not been implemented in the field of arts education in 2018. Thus, these two programs will not be discussed in this paper. Meanwhile, the In-Service Teacher Training Program (PLPG) is conducted by the government by assigning certain educational institutions to organize the program, whereas the Subject Teachers' Consultative Council is organized at the city/regency level and is collegial. 


\subsection{A Model of Teacher Development through In-Service Teacher Training Program}

In-Service Teacher Training Program or Pendidikan Latihan Profesi Guru (PLPG) supports teacher certification in Indonesia. The similar program in Australia is Initial Teacher Education (2014), in the U.S.A is known as The American Board for Certification of Teacher Excellence (U.S. Department of Education, 2001). To support teacher certification in Indonesia, there are two things emphasized in this training, namely the exploration of classroom action research referring to the one already conducted in teachers' respective classes and the development of learning media (Kemendikbud, 2012).

The purpose of classroom action research is to improve teaching and learning processes when the teachers find that their students did not meet the minimum standards as required. Before doing classroom action research, the teachers are encouraged to identify the problems about teaching and learning. This problem looks for the solution through writing research proposals. The proposals should be presented and discussed with the instructors and other teachers in the class of the training program. Then, the teachers should make lesson plans, using a strategy or an appropriate method. The result of this research is the teacher's reflection on better teaching and learning. Furthermore, the teachers learn how to develop lesson plans, students' activity documents, teaching materials, media, and assessment.

Improvement of teaching and learning starts from the cognitive development of teachers, which is then passed on to students through appropriate learning media. Individuals have two main cognitive systems, namely the presentative system underlying an understanding of the world and the procedural system relating to functions that ensure the proper performance of satisfying needs by creating or transferring procedures (Piaget, 1987: 5). These two systems must complement each other.

The $P L P G$ program focus on pedagogical competence, but personality competence especially regarding the current condition of Indonesian teachers related to Inclusive Schools are not recognized. This means that through this program teachers should be given a strong motivation and awareness of their profession so that they will carry out the teaching and learning whole-heartedly and sincerely, and not with the desire to get "instant" results of their education. Everything must be done slowly and gradually, but of course with the progress at each stage. Especially in dealing with students with special needs, the teaching and learning process must be carried out gradually, accompanied by the sincerity of educators in carrying out the process. Referring to four phases of professional development identified by Hargreaves (2000) PLPG relates to the pre-professional phase because the teachers' training program aims to refresh pedagogical competence in teaching and learning to better students' achievement.

The result of teacher training which focuses on classroom action research in reality is still far from expectation because there are still teachers who do not understand and rarely conduct classroom action research so that there has been no significant increase in student's learning outcomes from year to year. Teachers' "creativity" is only shown in the activity of searching for and copying the results of other people's work, be it a syllabus, lesson plan, or teaching material. This problem should not be allowed to drag on. There must be serious and comprehensive efforts made by relevant parties and those concerned with education to create quality and equitable education.

Regarding Inclusive Schools, observations made by the authors in 2018, reveal some interesting cases related to teacher competence and teacher professional development program. One of such cases is the one in which two inclusive school teachers who have not participated in the PLPG from different schools were found to be able to teach with love and compassion and managed to deliver teaching and learning to their students with positive progress, even though they did not have a teacher's educational background. More astonishing is the finding that the achievements of these two teachers exceeded those of other teachers who hold degrees in special needs education. The case teaches a good lesson that teachers must create a teaching and learning atmosphere that is as pleasant as possible so that students will feel comfortable and eager to learn. Thus, pedagogical competence must be equipped with personality competence.

\subsection{A Model of Dance Teacher Development through Musyawarah Guru Mata Pelajaran (MGMP)}

Efforts of developing teacher professionalism that has been made so far are: Taking part in scientific meetings facilitated by the Subject Teachers' Consultative Council or teacher workgroups, empowering teachers' competencies and encouraging them to participate in scientific forums/seminars/workshops held in and outside education offices, implementing education supervision programs by principals and supervisors, and conducting in-house training. These efforts are made to improve teachers' competencies in improving the preparation of learning media, including making lesson plans, planning learning methodologies, developing teaching materials, and evaluating learning outcomes.

Data from the results of preliminary observations in Bandung city schools in 2018 indicated that the problems faced by teachers do not only exist because of a lack of ability to choose and implement learning methods and strategies, but 
they also show weak pedagogical competencies. This is reflected in the way teachers treat and provide services to students, especially special needs students who attend inclusive classes. Teachers tend to only convey the subject matter contained in the student textbook, without understanding the learning guidelines that they have created and the context. As a result, students do not get a clear concept of the learning materials, and they also lack the courage and confidence to ask questions.

The problems call for the right solution, particularly in supervision. Based on the observations made in Bandung City, it is recommended to build a professional culture of collaboration to make teachers able to explore their opinions in an MGMP discussion forum. The topic of discussion can range from the formulation of lesson plans, development of teaching materials, development of learning strategies in inclusive classes, to the assessment of learning processes/outcomes. The discussion forum facilitates teachers to discuss the problems related to students' achievement problems. Also, teachers can share each other experiences in teaching and learning. These activities impact teachers' social competence development.

Referring to Hargreaves' four-phase identification (2000), MGMP is the collegial professional phase. Because the activities in MGMP are arranged by the teachers who teach certain subject matters, like the subject for arts and culture in schools. Wardoyo et al. (2017) said that the collegial professional phase is an effective way for the teacher's training program. However, the majority of teachers' training programs through MGMP rarely discuss the strategy and methods for teaching students with disabilities or students in inclusive schools.

\subsection{A Model of Teacher Development through Supervision}

Based on preliminary observations the first author conducted classroom supervision with the following stages: pre-observation (checking the availability of learning media) and observation (observing classroom learning processes based on the lesson plans previously made). The classroom observations during dance teaching and learning lessons show that: 1) the teachers observed did not make a good plan, as indicated by the lesson plan documents that did not specifically describe the classroom learning (the lesson plans were copied from other teachers without any modification or revision tailored to the conditions/characteristics of their school and students), 2) the teaching and learning process seemed monotonous; the teachers did not make any innovation in their teaching and learning strategies. Some teachers prepared lesson plans only to meet administrative demands, such as the promotion of their class/ rank and as part of the requirements for teacher certification, rather than as guidelines for conducting the teaching and learning process. Departing from the findings above and referring to Mulyasa's opinion (2009: 75) previously cited, it can be concluded that the teachers' competencies or skills/ expertise in the teaching and learning process have not been optimal.

The vital phase in fostering and developing teacher professionalism is supervision. The concept of supervision is closely linked to coaching or mentoring. This means that principals and supervisors serve as supervisors for teaching and learning or academic activities. Mantja (2002) defines supervision as a supervisor's activities (official positions) carried out to improve the teaching and learning process. Two objectives must be realized by supervision, namely: improvement of teacher-student and improvement of the quality of education. Ideally, supervision gives more emphasis on pedagogical competence. Mulyasa (2009: 75) identifies that pedagogical competencies at least cover the following aspects: (a) understanding of insights and educational foundation, (b) understanding of students, (c) curriculum/syllabus development, (d) learning design, (e) educational and dialogical learning implementation, (f) use of learning technology, (g) evaluation of learning outcomes (EHB), and (h) development of students to actualize the various potentials they have.

Ervina's research (2015) shows that the supervision of arts and culture teachers' pedagogical competencies at Junior High School was generally carried out by mentoring the teachers in the preparation of lesson plans, semester programs, annual programs, and assessment instruments. The mentoring in preparing learning media was more in the form of direction and assignments to the teachers. Supervisors did not do any follow-ups. Supervision was done by monitoring the instructional methods applied by the teachers through classroom observations and individual meetings. Supervision was also implemented through MGMP activities, even though it was only implemented once. The development of pedagogic competencies was also carried out by the principal, namely by establishing a school supervision team. The school supervision team provided mentoring with a predetermined schedule, namely at the beginning of the semester, and was carried out on an ongoing basis.

Her research also reported that the development of the personality competence of arts and culture teachers was carried out by giving directions to the teachers on how to behave and act. Teachers as educators must be able to be role models for students and the community. However, the supervisors did not create any activity that can shape the personality of the arts and culture teachers. They did not carry out monitoring and follow-up activities. The development of arts and Published by Sciedu Press 
culture teachers' social competence was done by providing directions for the teachers to establish good communication with students, fellow educators, and the community. The development of social competence was also carried out by the principal both in school and outside the school. The development in the school included family gatherings and social visits with colleagues and members of colleagues. Outside school activities included instructing teachers to take part in MGMP activities and to become members of the PGRI (Teachers' Union of the Republic of Indonesia). The supervisors did not follow up on the development of the teachers' social competence. They also did not conduct the supervision based on the stated objectives of arts and culture subject, in which teachers should be assisted to improve their communication skills with students in delivering the learning materials of arts and culture encompassing fine arts, music, dance, and theater.

Furthermore, Damayanti (2017) in her research reported that teachers in regular schools are required to have competencies in teaching students with special needs. Teacher competence here is defined as the ability to manage the learning of students with special needs, consisting of aspects of knowledge, understanding, abilities, values, attitudes, and interests, as a set of intelligent, responsible actions that the teacher has, and as a condition to be considered capable by the community in implementing teacher's duties (Decree of the Minister of National Education No. 045/U/2002, Article 1).

Through supervision activities, the supervisors closely work with the teacher individually. The supervisor observed how the teacher delivers content and how the teacher used methods of teaching and classroom management as well as evaluation. The teachers for arts and culture subjects at the secondary school level still have the problem to develop innovative teaching. Then, the supervisor discusses with the teacher to improve professionalism in particular, how to develop a teaching strategy for delivering the content. These supervisors' activities should be reported to the Head of Education and Culture Board in the level of City or District. The supervision activities relate to Hargreaves' four professional phases (2000), supervision meets the autonomous professional phase.

\subsection{A Collegial Model for Teachers' Competencies Development}

Teacher training programs for increasing teachers' professionalism as described above are conducted through the PLPG or In-Service Teacher Training Program, MGMP or Subject Teachers' Consultative Council activities at the school and regional levels, and school supervision. The PLPG focuses on improving pedagogy and professional competencies. MGMP tried to explore four competencies such as professional, pedagogy, personal, and social.

PLPG is conducted by the central government collaborating with the Higher Education, particularly UPI. This training program aims to increase teachers' professionalism for the teachers to get a certification as a professional teacher. However, when PLPG is over and the teachers get back to the schools, the government did not evaluate the teachers for professional sustainability. The teachers should be evaluated or supervised periodically to sustain their professionalism. MGMP is conducted by teachers based on their needs for professionalism and recharging knowledge and skills about teaching and learning. The local government, Education, and Culture Board supported their activity. However, when the district has a limited budget, MGMP does not conduct the activity, therefore, the teachers do not have the similar knowledge and skills with the teachers who get supports for some activities such as workshops, seminars, and conferences.

Regarding inclusive schools, no one teacher's training activities in Bandung City rose the issues and content related to students with special needs. When the PLPG program will be over and will be exchanged to Pendidikan Profesi Guru (PPG) or Professional Teacher Certification program, action research and the methodology of teaching, as well as the content, should urgently consider students with a disability as well. MGMP is the type of collegial model for teacher professional development, therefore, MGMP should collaborate with the researchers in Higher Education to sustain professional development activities that include the materials for students with disabilities.

\section{Conclusions}

The model of teacher professional development is generally carried out through in-service teacher training programs and other programs under the Subject Teachers' Consultative Council. However, there has been no post-professional development activity evaluation. The role of school supervisors is more administrative, focusing on learning design and student evaluation, while the practice of teaching and learning in the classroom has never been evaluated. Meanwhile, inclusive school policies require an evaluation of teacher professional development, especially in dealing with children with special needs in regular classes. Collegial teacher's training models, such as MGMP, are seen as more appropriate for improving sustainability competences. Indonesian teachers have a strong culture of communication and collaboration, and it turns out that teachers are more comfortable and happy to exchange information with peers. 
Pedagogical competence is closely related to the professionalism and professionalization of teachers. Teachers who have pedagogical competence are professional, albeit in a simple way. Professional teachers are needed in improving student learning outcomes, especially for inclusive schools. To obtain pedagogical competences requires determination from teachers who are dedicated to school teaching and learning and the meeting of the demands for students' academic achievement from parents, the community, or the government.

Based on the research findings, some recommendations can be drawn. Teachers in general, especially dance teachers, still need to strengthen their understanding of inclusive learning, even though they are not teachers of special education. Therefore, it would be much better if a teacher competence development program is implemented, especially in inclusive teaching and learning. Continuous supervision affects teacher competence in providing equitable education services by the needs of inclusive schools, in terms of classroom management, methods, materials, implementation of the teaching and learning process, and evaluation.

\section{References}

A. Chaedar Al-Wasilah, (2011). Pokoknya Kualitatif,. Jakarta: Dunia Pustaka Jaya. Cetakan ke VI.

Biesta, G. J. J., \& S. Miedema (2002). Instruction or pedagogy? The need for a transformative conception of education. Article: $\quad$ Teaching and Teacher Education-Pergamon, 18, 173-181. https://doi.org/10.1016/S0742-051X(01)00062-2

Bloom, B. S. (1956). Taxonomy of educational objectives. London: Longmans.

Damayanti et all. (2017). Kompetensi Guru Di Dalam Proses Pembelajaran Inklusi Pada Guru Sd Negeri Di Kota Bandung. Schema: Journal of Rsychological Rearch. https://ejournal.unisba.ac.id/index.php/schema/article/view/1947. https://doi.org/10.29313/schema.v0i0.1947

Daniel, J. R., \& Cooc, N. (2018). Teachers' perceptions of academic intrinsic motivation for students with disabilities. The Journal of Special Education, 00(0), 1-12. https://doi.org/10.1177/0022466918765276

Decree of the Minister of National Education of the Republic of Indonesia Number 045/U/2002 concerning Core Curriculum of Higher Education. (A Copy).

Ervina (2015). Pembinaan kompetensi guru seni budaya oleh pengawas (studi deskriptif kualitatif di SMP Negeri 1 Kota Bengkulu) [Development of arts and culture teacher competence by supervisor: a descriptive qualitative study at State Junior High School 1 Bengkulu City].Masters thesis (Unpublished), Universitas Bengkulu.

Hakim, A. (2015). Contribution of competence teacher (pedagogical, personality, professional competence, and social) on the performance of learning. The International Journal Of Engineering And Science (IJES), 4(2), 01-12.

Hargreaves, A. (2000). Four ages of professionalism and professional learning. Teachers and Teaching: History and Practice, 6(2), 151-182. https://doi.org/10.1080/713698714

Jazuli, M. (2008). Pendidikan seni budaya suplemen pendidikan seni tari. Semarang: Unnes Press.

Kemendikbud (2012). Tentang Kebijakan Peningkatan Layanan Melalui Pendidikan Inklusif. Kementerian Pendidikan dan Kebudayaan Direktorat Jenderal Pendidikan Dasar (a copy).

Klaassen, C. A. (2002). Teacher pedagogical competence and sensibility. Article: Teaching and Teacher Education-Pergamon, 18, 151-158. https://doi.org/10.1016/S0742-051X(01)00060-9

Law No. 14, 2005 regarding Teacher and Lecturer. (A Copy)

Lepper, M. R., J. H. Corpus, \& S. S. Iyengar (2005). Intrinsic and extrinsic motivational orientations in the classroom: Age differences and academic correlates. Journal of Educational Psychology, 97, 184-196. https://doi.org/10.1037/0022-0663.97.2.184

Liakopoulou, M. (2011). Teachers' pedagogical competence as a prerequisite for entering the profession. European Journal of Education, 46(4), 474-488. https://doi.org/10.1111/j.1465-3435.2011.01495.x

Lynch, J. (1994). Provision for children with special educational needs in the Asia region. World Bank: World Bank Technical Paper, Asia Technical Department Series. https://doi.org/10.1596/0-8213-3036-5

Mantja, W. (2002). Manajemen pendidikan dan supervise pengajaran (Management of education and teaching supervision). Malang: Wineka Media

Mirzagitova, A. L., \& L. G. Akhmetov (2015). Self-development of pedagogical competence of the future teacher. International Education Studies, 8(3), 114-121. https://doi.org/10.5539/ies.v8n3p114 
Mulyasa, E. (2009). Standar kompetensi dan sertifikasi guru (Competence standard and teacher certification). Bandung: Remaja Rosdakarya.

Ngainun, Naim. 2009. Menjadi guru inspiratif: Membudayakan dan mengubah jalan hidup siswa. Yogyakarta: Pustaka Pelajar.

Piaget, J. (1987). Possibility and Necessity: The role of possibility in cognitive development, 1. Minneapolis: University of Minnesota Press.

Piaget, J. (1999). The construction of reality in the child. Oxon: Routledge. https://doi.org/10.4324/9781315009650

Power, B., \& C. Klopper (2011). The classroom practice of creative arts education in NSW primary schools: A descriptive account. International Journal of Education \& the Arts, 12(11), 1-26.

Puri, M., \& Abraham, G. (eds., 2004). Handbook of inclusive education: for educators, administrators, and planners. New Delhi: Sage Publications.

Ramdhani, D. (2015). Ridwan Kamil Wajibkan Tiap Sekolah Terima Anak Penyandang Disabilitas (Ridwan Kamil makes it compulsory for teachers to accept children with disabilities). https://regional.kompas.com/read/2015/10/26/14455331/

Regulation of the Government of the Republic of Indonesia Number 19 of 2005 regarding Standards of National Education (a copy).

Ridwan.Kamil.Wajibkan.Tiap.Sekolah.Terima.Anak.Penyandang.Disabilitas. Retrieved August 20, 2018.

Suciu, A., \& L. Mâţă (2011). Pedagogical competences - The key to efficient education. International Online Journal of Educational Sciences, 3(2), 411-423.

Susanto, A. (2011). Teori belajar dan pembelajaran di sekolah dasar (Learning Theory in Elementary School). Jakarta: Prenadamedia Grup.

Taboada, A. et al. (2009). Effects of motivational and cognitive variables on reading comprehension. Reading and Writing, 22, 85-106. https://doi.org/10.1007/s11145-008-9133-y

The Teacher Education Ministerial Advisory Group [acronymTEMAG)]. (2014). https://www.education.gov.au/teacher-education-ministerial-advisory-group. Retrieved January $15^{\text {th }}, 2020$.

U.S. Department of Education (2001). Self-Paced Teacher Certification. https://www.americanboard.org/ start-a-new-career/. Retrieved January $15^{\text {th }}, 2020$.

Wardoyo, C., A. Herdiani, \& Sulikah (2017). Teacher professionalism: Analysis of professionalism phases. International Education Studies, 10(4), 90-100. https://doi.org/10.5539/ies.v10n4p90

West Java Province. Bandung Municipality Regional Government Regulation Number 2 of 2018 concerning Education Management and Implementation (a copy).

Yunus, S. (2017). Mengkritisi Kompetensi Guru. https://news.detik.com/kolom/d-3741162/mengkritisi-kompetensi-guru Retrieved November $1^{\text {st }}, 2018$.

\section{Copyrights}

Copyright for this article is retained by the author(s), with first publication rights granted to the journal.

This is an open-access article distributed under the terms and conditions of the Creative Commons Attribution license (http://creativecommons.org/licenses/by/4.0/). 